\title{
Governmental Context Determines Institutional Value: Independently Certified Performance and Failure in the Spanish Newspaper Industry
}

Manuel Núñez-Nickel, Isabel Gutiérrez and Salvador Carmona

Manuel Núñez-Nickel Carlos III University, Getafe, Spain

Isabel Gutiérrez Carlos III University, Getafe, Spain

\section{Salvador Carmona} Instituto de Empresa Business School, Madrid, Spain

\begin{abstract}
Many societies demand that independent professionals (e.g. auditors) certify the performance of firms. The value placed on such certification (i.e. the public perception of reliability/unreliability that may impact on an organization's success/failure) is not uniform, however, but contingent upon changing political contexts. This study presents and analyses data on the entire population of newspapers in Spain from 1966 to 1993, a time of peaceful transition from military dictatorship to capitalist democracy. Our results highlight the contingent nature of institutional life, demonstrating how changes in political contexts are associated with varying understandings of institutions. In particular, our findings support the prediction that, under a dictatorship, independently certified performance is not instrumental in organizational success or failure whereas, in a modern democracy, the certification process has a positive effect on the survival chances of firms.
\end{abstract}

Keywords: independently certified performance, institutional sociology, political regimes, newspaper organizations, organizational failure, Spain

Pressures for certified performance stem from the information asymmetries that characterize a firm's relationship with its external stakeholders (Biglaiser 1993; Lizzeri 1999). As noted by institutional sociologists, these pressures have become institutionalized (Scott 2001), with many societies demanding that independent professionals (e.g. auditors) certify the performance of firms (cf. Watts and Zimmerman 1983). Meyer and Rowan (1977) and DiMaggio and Powell (1983) suggest that a firm may improve its chances of survival if it bows to these institutional pressures and submits to certification, but this is not a foregone conclusion: the effects of the process are ultimately contingent on environmental complexity. As noted by Scott and Meyer (1994), political contexts exert an especially enduring and salient influence on institutional life, yet, in spite of the importance of the political scene, little is known about the extent to which the value is attributed to independent certification of performance. In particular, we still have much to learn about the role of such certifications in the failure of firms as well as how such effects could vary across political regimes. Dobrev (2001: 419) explains this lack of research as being due mainly to the fact that the vast majority of organizational studies draw on evidence gathered 
from industrialized societies that 'have experienced a relatively uninterrupted pattern of political and economic development'.

Currently, more scholars are examining the political contexts of firms. In a recent Special Topic Forum (Ring et al. 2005), the Academy of Management Review examined how industry creation and economic development at national and global levels can be fostered by government action (Mahmood and Rufin 2005), as well as the impact of deregulation on the governance mechanisms of firms (Kim and Prescott 2005).

In this study, we examine how the value attributed to independently certified performance, with its ramifications for a firm's survival, is affected by changes in the political context. Our investigation is supported by empirical evidence drawn from the entire newspaper industry in Spain, covering all the daily newspapers published in this country from 1966 to 1993. The enactment in 1966 of the Law of Press and Printing (LPP), which established sources of data that enable the tracking of developments in the newspaper industry, marks the beginning of our observation period. Midway through, it witnessed the fall of General Francisco Franco's military dictatorship, which had been in power since 1939, and its peaceful replacement by a fully fledged democracy (1978 till the present). The final year of analysis - 1993 — is marked by the start of the single European market and the consequent emergence of media groups in the country.

We focus on newspapers because these organizations produce informationloaded products while combining commercial and political aims (Carroll 1995). The industry is thus particularly vulnerable to institutional pressures for independently certified performance, and clearly demonstrates the effect of certification on a firm's survival — or otherwise - when mediated by politics.

The remainder of this paper is organized as follows. In the next section, we examine the changing context of the newspaper business in Spain, which shifted from state censorship and intervention, during the dictatorship, to the freedom of speech and liberalization of the economy that characterize a democracy. Our discussion then addresses the extent to which the value attributed to independent certification and the ultimate likelihood of firm failure, which is a potential consequence of such processes, is influenced by different political regimes. This section is followed by a description of our research setting, methods and findings. Finally, we discuss the results of this investigation and make some suggestions for future research in this area.

\section{The Institutional Contexts of the Newspaper Industry in Spain}

\section{The Dictatorship}

Between 1939 and 1975, General Francisco Franco headed a military dictatorship in Spain, enforcing, via the Falange Española, the fascist ideology of rule by a single party. State intervention characterized every aspect of economic and social life, with severe censorship, in particular, of the newspaper industry, and the setting up of the 'party press': a network of dailies that acted as a formidable apparatus of political propaganda (Bordería Ortiz 2000). 
In order to garner international support, however, the initially harsh, repressive regime underwent some reforms during the late 1950s and early 1960s. Many commentators note, in particular, the promulgation of the Law of Press and Printing (LPP) in 1966 (Sevillano Calero 1998), which targeted such crucial issues as freedom of speech and of the press. Censorship was abolished, along with the restrictive requirements for establishing new dailies, though the government retained the power to grant or refuse a licence to publish newspapers. In addition, the appointment of newspaper editors, which previously came under the jurisdiction of the Minister of Interior, was placed in the hands of the board of directors (Terrón Montero 1981: 189).

The LPP implemented measures to liberalize the marketing of newspapers and to make dailies more transparent for readers, advertising agencies and advertisers. In addition, in light of the general agreement that data on such crucial performance measures as newspaper circulation figures were unreliable (Aguado Guadalupe 1996; Bordería Ortiz 2000), the LPP endorsed the Oficina para la Justificación de la Difusión (OJD) to perform circulation audits. The OJD was an independent, not-for-profit organization comprising advertisers and advertising agencies along with representatives of dailies and magazines. Its work paralleled that of foreign associations such as the Audit Bureau of Circulations (founded 1914 in the USA) and the French Office de Justification des Tirages (founded 1923), which had already joined the International Federation of Audit Bureaus of Circulation (IFABC). The OJD soon joined the IFABC, thus gaining the endorsement of the international auditing community.

The OJD was legally compelled to provide its services to any newspaper that requested them, in return for a small professional fee. Its charges were based on a newspaper's circulation, with the average annual fee representing just $15 \%$ of one day's total turnover. Significantly, newspapers had to volunteer for auditing: they were neither obliged to render information nor to submit to an audit by the OJD. Those that did request audits, however, had to accept extensive examinations of the operational processes, and data stored, in their headquarters, administrative offices, production workshops and distribution networks, as well as in external firms to which any processes, such as production, might have been outsourced. Examination of accounting records, the consumption of press paper, registration of regular paid and unpaid newspaper subscribers, transactions with suppliers, and any other internal or external documents, all fell within the remit of the OJD inspectorate. The bulletin of the association published the results of the OJD audits, which listed the circulation, sales and observation period for all audited newspapers. Audited newspapers were allowed to display the logo of the OJD on their front page, with OJD audits being regarded by all in the newspaper industry as comprehensive and accurate (Aguado Guadalupe 1996: 89-91).

The implementation of the LPP reforms should be assessed, however, in the context of the dictatorship of General Franco, which was a political regime that mastered window-dressing to gain international recognition (Sevillano Calero 1998). Despite the law's liberal aims, in actual practice newspapers and magazines were recalled whenever any published piece failed to conform to party ideology (Álvarez 1989). For example, a few weeks after the implementation of the LPP, the newspaper $A B C$ published a pro-monarchy article entitled 
'The monarchy of everyone'. All issues of the newspaper were recalled from distribution (Fernández Areal 1971: 315), and the paper was subsequently fined - even though General Franco planned to appoint Prince Juan Carlos de Borbón his successor as head of state.

Many newspapers suffered temporary suspensions and recalls after the enactment of the LPP. In the province of Valencia, between January and March 1969, the publication of the following newspapers was suspended: Jornada, Levante, Las Provincias, Hoja del Lunes, Cartelera Turia, Diverama (Bordería Ortiz 2000: 255). Furthermore, repeated offences resulted in permanent bans, as happened with the daily newspaper Madrid. In reality, therefore, the LPP could do little to mitigate the restrictions imposed by the regime on the press. In 1971, senior journalists were asked, 'What does freedom of the press mean to you?', provoking such answers as: 'Nostalgia for something I have never known' (Eduardo Haro Tecglen, see Fernández Areal 1971: 284).

General Franco died in November 1975. The suppression of single-party rule swiftly followed, with the first free general elections to a democratic parliament being held in June 1977.

\section{The Democratic Period}

The liberal constitution of 1978 enshrined the fundamentals of a democracy, with extensive legislative reforms of the early 1980s establishing civil and political rights. In the process, newspapers formerly affiliated with the single party were either privatized or closed (Bordería Ortiz 2000). In respect of the LPP, while many of its crucial elements, including the OJD, remained formally unchanged, the actual work of the latter benefited from the new market economy and the concomitant reliance, of those in newspapers and associated industries, on bodies that would independently attest to corporate performance (Aguado Guadalupe 1996).

The year 1993 saw the strengthening of both economic and political ties within the European Community, with the inauguration of the Single European Market and ratification of the Treaty on the European Union. In anticipation of these developments, Spain enacted further measures to liberalize its economy. A consequence of these reforms was the emergence of media corporations that amalgamated daily newspapers with radio and television networks.

\section{Certified Performance, Political Contexts and Failure of Firms}

The steady globalization of markets and increasing need of firms for large-scale capital have increased the distance between their management and stakeholders. As Imhoff (2003) notes, this has prompted societal innovations to augment trust among those involved in the business relationship, a process illustrated by the emergence and development of the 'rationalized profession' of auditing (Meyer and Rowan 1977). By exposing their internal attributes and outcomes to independent certification (e.g. through financial audits), firms comply with institutional pressures and their associated rules and norms (e.g. technical procedures of accounting); reassure external stakeholders that business activities are subject 
to significant controls (Salancik and Meindl 1984; Scott 1995: 33); and avoid charges of 'negligent or irrational behavior' (Meyer and Rowan 1977). The annual publication of certified accounts renders firms reliable and stable in the public eye, investing them with legitimacy over time (Scott 1995). In other words, it contributes to 'the generalized perception or assumption that the actions of an entity are desirable, proper, or appropriate within some socially constructed system of norms, values, beliefs and solutions' (Suchman 1995: 574). In short, independent certification provides firms with support, increases their access to resources and diminishes the probability of their failure. As Hannan et al. (1998: 281) observe: 'Not all organizations can achieve reliability and accountability; those that do have survival advantages.'

It is possible, then, to conceive of an overt relationship between independently certified performance and organizational survival, such that firms whose performance has not been certified by independent professionals will ultimately be selected out. Nevertheless, because institutions are not monolithic and do not always elicit compliance and agreement from organizations, leading institutional theorists have asserted that institutional influence on firms can decrease, as well as increase, over time (Mezias and Scarselletta 1994: 654; Scott and Meyer 1994). The value placed on independently certified performance would arguably vary over time and across organizations, as do many other normative prescriptions arising from a firm's broader, socio-cultural environment (Dacin 1997).

Political systems constitute a central element of this environment (Meyer and Scott 1983). Institutional sociologists and political scientists alike argue that political regimes exert an enduring influence on the 'many positions, policies, programs, and procedures' of firms and may help explain the varying effects of societal demands on organizations (Meyer and Rowan 1977; Skopcol 1985). This influence, we argue, affects the domain of institutional pressures for independent certification of a firm's performance, a terrain in which political systems show varying practices (Pye 1963; Stepan 1978).

Despite the differences between dictatorships and democracies, the former often draw upon the language and institutions of the latter to garner support from domestic public opinion and international observers (Bobbio 1989) — by enforcing, inter alia, laws that superficially mimic those enacted by constitutional democracies to improve civil and political rights and standardize economic institutions (Rao 1998). In particular, reforms promoted by dictatorships to signal their apparent respect for such fundamental rights as freedom of speech and freedom of the press ultimately result in a deep conflict between actual values and the practical implications of enacted legislation (Meyer et al. 1987). In the case of dictatorships, legislation that promotes freedom of the press goes hand in hand with continuous use of the state's apparatus of compulsion, to monitor compliance of newspapers with the official doctrine and to enforce sanctions against those departing from it.

Hence, the survival of newspapers in a dictatorship requires, first and foremost, conformity with the beliefs and values that prevail in the wider political system. Otherwise, dailies face sanctions that place their financial feasibility at risk and lessen their social support, or even face permanent bans (Álvarez 1989). In such an environment, despite legal endorsement, institutional pressures for 
independent certification of the performance of daily newspapers involve not so much social worthiness as ideological compliance.

The governments of democracies do not train the supervisory gaze of the state on the contents of newspapers. Indeed, the converse is true: in capitalist democracies, governments make themselves accountable both before parliament and to wider public opinion (Friedrich 1950), a process in which newspapers are intimately involved, that results in monitoring governmental action and presenting it to the public. Thus, the power of external stakeholders shifts from the nation state towards third parties such as readers, advertising agencies and advertisers, who become the main providers of support and access to material resources; accordingly, the dailies' contents shift towards compliance with demands for editorial consistency and independent certification of their internal attributes and outcomes. Consequently, the social worthiness attached to certified measures of performance is higher in democracies than in dictatorships (Bobbio 1989), a difference that may be instrumental in the failure of newspapers when operating under a different political regime. Thus, we hypothesize as follows:

H1: The organizational failure value of independently certified performance depends on the political context. If the political context is a dictatorship, then independently certified performance does not impact on organizational failure, but if it is a capitalist democracy, independently certified performance decreases organizational failure.

\section{Research Setting}

For this study, the organizational population comprised the entire newspaper industry of Spain: all daily newspapers published during the period 1966-1993 are included. 'Newspapers' (or 'dailies') are defined here as periodicals published at least four times a week, whether general or specialist (e.g. sports, medicine), and covering either national or local markets. This definition meets the criteria for a single population of organizations, a unit of analysis common in institutional sociology (Dobrev 2001; Dacin et al. 2002).

One trait of this population is the low-to-medium level of its circulation by international standards. Valls (1986: 58-59) attributes a value of 1 to Spain in the consumption of newspapers per adult person during 1985, as compared to newspaper consumption in such selected industrialized countries as Japan 7.2, UK 5.3, Germany 5.16, USA 2.7, France 2.4 and Italy 1.05 .

\section{Sources of Data}

Our database has been created from three separate primary sources established as a consequence of the promulgation of the LPP: a founding registry, a media guide and the OJD reports. The first source of data is the Registro General de la Administración Pública (Registry of the Spanish Public Administration), which contains a census of all the daily newspapers founded in Spain since 1966. On the day of foundation, firms are obliged to deliver to the Registry the 
following general information: newspaper name, list of founders, ownership structure, number of pages, price of one issue, contents of the newspaper (e.g. general, sports) and the firm's address. Some of this information, such as the ownership structure of the firm, is, however, kept confidential.

The second source is the Guía General de Medios de Comunicación Social (Media Guide of Spain), a quarterly publication that provides data on the exact date a failed newspaper ceased operations. The guide also provides some detailed information on each firm: the state of its information technology; the names of its editor, CEO and advertising manager; the exact date of succession of these senior executives; the design features of newspaper issues, and advertisement rates; and, until 1977, its membership in the state political party, if applicable.

The third source of data is the reports produced by the OJD. As noted in the above discussion, from 1966 to 1991 the OJD was the only possible means by which newspapers could undergo regular, independently certified assessments of their attributes and outcomes. We do not expect a sample size bias, both because the professional fees of the OJD were relatively low and contingent upon circulation and frequency, and because large and small firms equally had to comply with the same audit requirements.

\section{Period of Study}

Our period of study extends from 1966 to 1993. To account for the changes experienced by the newspaper industry, we have divided it into two sub-periods: Dictatorship (1966-1977) and Democracy (1978-1993).

\section{Operationalization of the Variables}

The dependent variable in this study is firm failure, defined as 'permanent cessation of operations'. This variable assumes a value of 1 (one) for firms that failed and 0 (zero) for firms that did not.

We have analysed the effect of the audit on firm failure through the independent variable circulation audits - a dummy variable for each period, which takes a value of 1 if the newspaper was audited by the OJD and 0 if it was not.

As we noted at the outset of this paper, hazard rates are, of course, also influenced by factors other than circulation audits. Drawing on the vast empirical work of population ecologists on newspaper organizations (e.g. Carroll and Delacroix 1982), we have controlled for institutional, organizational and environmental variables to test the robustness of our models.

We have accounted for the political contexts of newspaper organizations through the variable era. This variable takes a value of 1 for the years of dictatorship and 0 during the period of democracy.

To test for the joint effects of circulation audits and political contexts on firm failure, we have calculated the interaction of both variables, era * circulation audits.

Five organizational attributes serve as control variables. Newspaper contents are controlled through three dummy variables (Carroll 1985; Miner et al. 1990), which take a value of 1 where the newspaper's contents could be characterized 
as either general, sports or economic, and 0 if the daily was dominated by one or more specialized subject matters (e.g. medicine, ship transportation).

Size is controlled with the use of two dummies representing geographic coverage: national coverage for newspapers distributed to at least 15 Spanish provinces; regional coverage for dailies distributed to 14 or fewer Spanish provinces but to more than one. Both variables are coded 1 when the newspaper had the characteristic that defined it, and 0 when it did not.

We have entered a dummy control variable to reflect the impact of belonging to the single political party (Miner et al. 1990). This variable — party affiliation - is given a value of 1 if the newspaper was owned by the single political party, and 0 if it was not. With the dissolution of the Falangist party, its newspapers passed into state ownership and were subsequently either closed or privatized. The variable has been maintained during the period that the state privatized or closed these newspapers.

We controlled for any subsidy from the state to newspapers through a dummy variable that has been given a value of 1 if the newspaper received a subsidy from the Spanish government, and 0 otherwise.

Language is a crucial element for newspapers (Dacin 1997). We have coded it 1 if the paper was published in Spanish, Catalan or Basque, and 0 if it was not. Languages coded 1 were the official ones either of the country (Spanish) or of an autonomous region (Catalan and Basque), a status with political implications, and one that provided market opportunities to newspaper organizations.

We also used several variables to control for environmental effects. Competition was measured through population density (Carroll and Hannan 1989; Miner et al. 1990), which was defined as 'the total number of newspapers that existed during any given period' (Dobrev 2001) and density ${ }^{2} / 100$. These variables were chosen because of the positive relationship that population ecologists have found between population density and mortality rates (e.g. Baum and Korn 1996; Baum and Mezias 1992).

Niche width can be seen as a measure of the market prospects of a population of organizations. The present study defines the market prospects of the newspaper industry of Spain as 'the population of literate people older than 16 years (in millions)'. Values for this variable were gathered from the Encuesta de Población Activa (Labour Force Survey), a quarterly report published by the Instituto Nacional de Estadística (Spanish National Bureau of Statistics).

We used the Gross National Product (GNP, in million pesetas) as an indicator of the economic climate of the country (Carroll and Delacroix 1982). Information about the GNP was collected from the reports of the Organization for Economic Cooperation and Development (OECD). To measure GNP trends during this period, GNP data are shown in constant currency in comparison with the GNP value of 1986, as provided in the OECD reports.

A further variable, which controlled for activity in the newspaper industry, was based on information about the consumption of newsprint (in 100 million tonnes), provided by the OECD reports.

We also created a control variable related to the newspaper-reading habits of people living in northern vs. southern regions of Spain. Newspapers that were 
distributed in northern regions are coded 1 , and those that were not are coded 0. Traditionally, northern regions and provinces have higher levels of education and income per capita than their southern counterparts (La Caixa 2005).

Age was defined as the 'number of years between the date of a newspaper's founding and its disbanding' or — if the daily was still alive at the time 'between the date of its founding and the end of the analysed period'. Because it is necessary in studies on organizational mortality to introduce a control variable to overcome the left-truncated data, we use 12 age-defined intervals to control for age-dependence in mortality (Carroll and Hannan 2000).

Finally, circulation audits could arguably be an endogenous and self-selected variable. In other words, some newspaper organizations might seek to have their performance independently certified because of their poor results, which would have influenced circulation audits with effects similar to those affecting our dependent variable, firm failure. Such a situation would have introduced a selection bias into our regression analysis of the effects of circulation audits on failure (e.g. Greene 1993; Heckman 1979; Maddala 1983). Heckman (1979), however, demonstrates that including the inverse of Mill's ratio in the models as a control variable can resolve this problem. To calculate this variable (correction for self-selection), we have followed the empirical application developed by Shaver (1998: 581): we estimate one probit model for each period, where circulation audits is the endogenous variable in this model. We have coded it 1 if circulation audits were performed and 0 if they were not. If we consider that these models have the following structure:

$$
\text { Circulation audits/No circulation audits }=\gamma^{\prime} w+\varepsilon,
$$

we can calculate the new control variable as a function of the following criteria:

Self-selection $=\phi\left(\gamma^{\prime} w\right) / \Phi\left(\gamma^{\prime} w\right)$, if the firm performed circulation audits

Self-selection $=-\phi\left(\gamma^{\prime} w\right) /\left[1-\Phi\left(\gamma^{\prime} w\right)\right]$, if the firm did not perform circulation audits

The exogenous variables $(w)$ in these models refer to the organizational ones described in the above discussion: the contents of dailies, their size, party affiliation, subsidy, and languages.

\section{Model}

We used the Piecewise-Weibull Model with a hazard rate:

$$
r(t)=\delta \exp [\beta \mathrm{X}(t)]^{\delta-1}
$$

where $\beta$ is the associated vector of coefficients, $X$ the matrix of exogenous and control variables and $\delta$ the Weibull's location parameter. The Weibull distribution maximizes the log-likelihood in the regressions and provides the best fit according to Akaike and Schwarz's criteria (see Table 1).

The values of the different variables were introduced in three-month splits, the smallest possible intervals in our database. As noted above, this model allows a solution of the left-truncated data problem by including organizational age as a control variable (12 segments in our case) and by using calendar time as the dependent variable, which allows us to estimate the hazard rate, $r(t)$ 
Table 1. Model Fit

\begin{tabular}{lccc}
\hline Distribution & Akaike's Criterion & Schwarz's Criterion & Log-likelihood \\
\hline Weibull & $\mathbf{- 1 9 7 . 4 5 0 6}$ & $\mathbf{- 2 3 1 . 5 6 3 2}$ & $\mathbf{- 1 6 5 . 4 5 0 6}$ \\
Log-logistic & -201.2154 & -235.3280 & -169.2154 \\
Exponential & -217.5826 & -251.6952 & -185.5826 \\
Gamma & -247.2028 & -281.3154 & -215.2028 \\
Log-normal & -259.3397 & -293.4523 & -227.3397 \\
Cox Model & -508.2120 & -530.5984 & -487.2120 \\
\hline
\end{tabular}

(Dobrev and Carroll 2003; Ingram and Simons 2000). We used the maximum partial likelihood and the statistical package Stata 6.0 (Stata Corporation 1999) to estimate all $\beta$ parameters (Cox and Oakes 1984; Lawless 1982). If $\beta$ had a positive and significant sign, it would mean an increase in an organization's probability of failure. Alternatively, if the sign were negative and significant, this would indicate a reduction in the probability.

\section{Results}

The total population of newspapers consisted of 276 entities, 118 of which were in operation at the beginning of the observation period in 1966. Of the total, 238 dailies were classified as having general contents, 9 had a sports focus, and 8 dealt with economic contents. The remaining 21 newspapers had a more specialized focus (e.g. shipping, medicine). In respect of geographical scope, 30 dailies targeted the national audience, 56 papers regional audiences, and 190 local audiences. Population density peaked during the period 1978-1989, which witnessed a political transformation from the institutions of the dictatorship to those of a capitalist democracy, leading to an increase in the number of newspapers, from a total of 147 that were in operation at any point between 1966 and 1977 to a total of 232 for 1978-1989 (Hannan and Freeman 1989: 425). The population then slumped to a total of 167 in the last four years of our observation period. Our data showed a dramatic increase in the number of newspapers audited at least once by the OJD, from $25 \%$ of the population during the dictatorship (1966-1977) to $60 \%$ during the last four years of our observation period (1990-1993).

The network of newspapers affiliated with the single party consisted of 42 entities. No such newspapers failed under the dictatorship, but 26 did so either immediately after Franco's death, in 1975, or right after the consolidation of democratic institutions in Spain (1982-1984). There is not a single case of failure within this political group after 1984. In total, 16 Falangist party newspapers survived. Twelve of these had undergone OJD audits during the dictatorship. The remaining four (Diario Español, El Correo de Zamora, La Gaceta Regional and Nueva España) did not independently certify performance under the dictatorship, but performed OJD audits right after the advent of democracy.

The means, standard deviations and Spearman correlations among the variables used in this study are shown in Table 2 . 


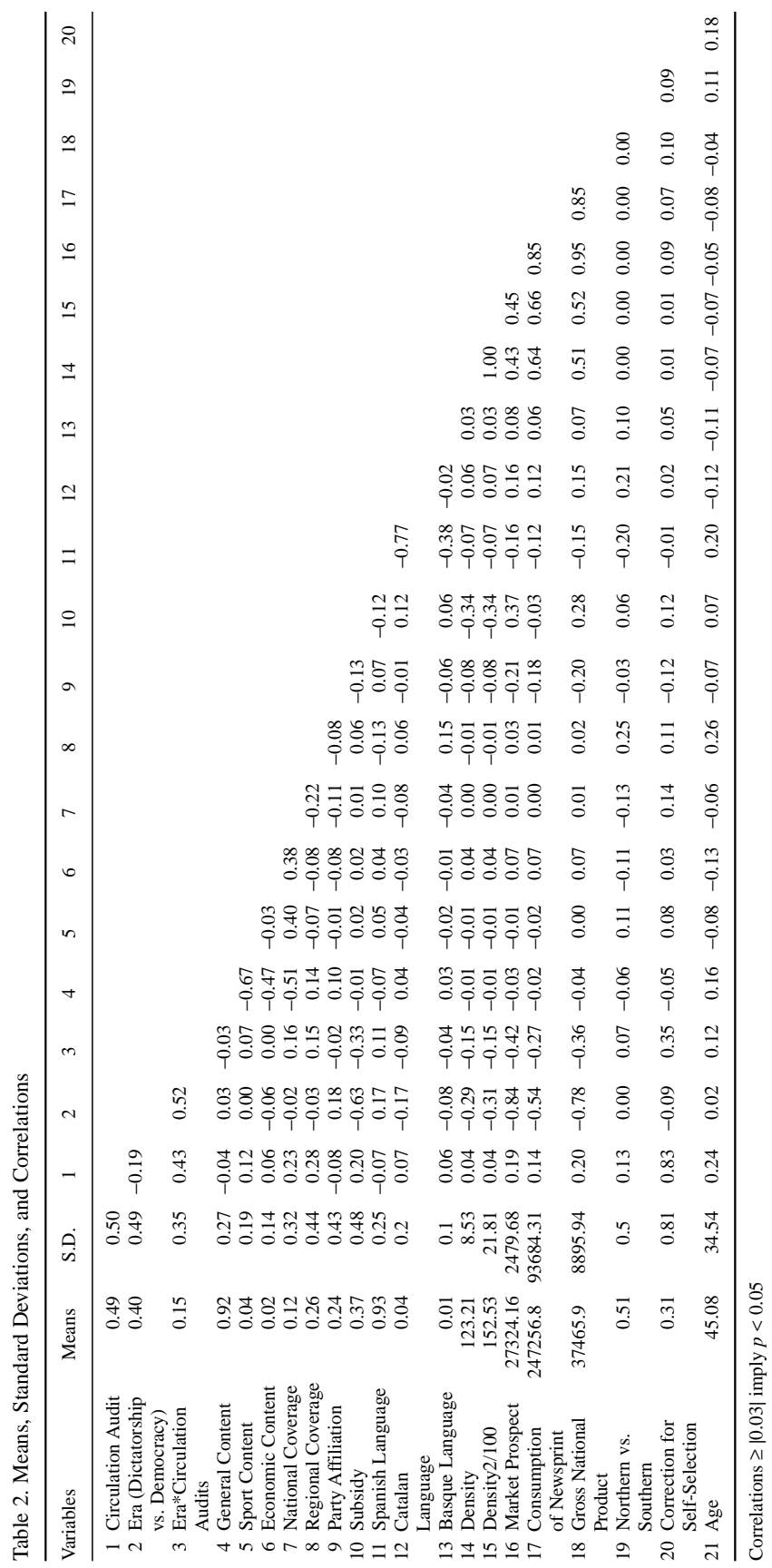


To test for the selective effects of independently certified performance on firms under varying political regimes, we calculated three regressions. Model 1 in Table 3 shows the results for the entire observation period (1966-1993). It includes the variable era $*$ circulation audits, which accounts for the interaction between political regimes and circulation audits. The second and third regressions refer to the dictatorship era (Dictatorship: Model 2, 1966-1977) and the democratic period (Democracy: Model 3, 1978-1993), respectively.

Our hypothesis would be supported if the coefficients for the independent variable (circulation audits) were negative and statistically significant for the Democracy, but not statistically significant for the Dictatorship. The results shown in Models 2 and 3 do support our hypothesis. In the Democracy model, the coefficient of circulation audits was negative and statistically significant $(-4.7158 ; p<.0001)$. Moreover, the coefficient for the Dictatorship model was not significant $(p \approx 1)$.

We found similar results in Model 1. Independently certified performance did not exert a significant influence on the failure chances of firms during the Dictatorship; the coefficient of the variable era * circulation audits was not significant (see Model 1, Table 3). Once we isolated the joint effects of era and circulation audits, our results showed that newspapers that received independent certifications of their outcomes had lower failure rates than did their counterparts that did not receive such certifications $(-4.6011: p<.0001)$.

We found differences in mortality rates before and after 1977; the coefficient of era (Dictatorship vs. Democracy) is negative and significant $(p<.05)$, and therefore indicates that the chances of newspaper failure were lower before 1977, during the Dictatorship, than they were during the Democracy.

For the Dictatorship we found only one case of statistical significance among our control variables: density with its quadratic transformation $(p<.05$; see Model 2, Table 3). In contrast, for the Democracy, significant control variables were somewhat similar to those obtained for our entire observation period. The positive coefficients of sport content and party affiliation indicate higher chances of organizational failure. However, those newspapers that received a subsidy (with negative coefficients) had lower hazard rates. Consumption of newsprint, market prospect, and northern vs. southern constitute the sole three cases of significance during the Democracy, with $p<.01$ for the first one and $p<.05$ for the latter two.

\section{Discussion}

A significant number of countries and regions have experienced considerable changes in their political regimes over the past years (e.g. South America, Eastern Europe), making them relevant settings for highlighting the extent to which firms may be influenced by changes occurring in their wider political contexts. In the present study, we test whether such changes affect the value attributed to independently certified performance, as well as the consequences associated with the process (e.g. organizational failure). 
Table 3.

Impact of Audit on Failure Chances

\begin{tabular}{|c|c|c|c|}
\hline & $\begin{array}{c}\text { Model } 1 \\
\text { Total Period } \\
(1966-1993)\end{array}$ & $\begin{array}{c}\text { Model } 2 \\
\text { Dictatorship } \\
(1966-1977)\end{array}$ & $\begin{array}{c}\text { Model } 3 \\
\text { Democracy } \\
(1978-1993)\end{array}$ \\
\hline Circulation Audits & $\begin{array}{l}-4.6011 \text { ***** } \\
(0.7641)\end{array}$ & $\begin{array}{r}-33.6439 \\
(7668051)\end{array}$ & $\begin{array}{l}-4.7158 * * * * \\
(0.7842)\end{array}$ \\
\hline Era (Dictatorship vs. Democracy) & $\begin{array}{l}-1.3663 * \\
(0.6675)\end{array}$ & & \\
\hline Era*Circulation Audits & $\begin{array}{r}-10.6635 \\
(503.7938)\end{array}$ & & \\
\hline General Content & $\begin{array}{l}1.6349 * \\
(0.7911)\end{array}$ & $\begin{array}{r}20.1554 \\
(689.5156)\end{array}$ & $\begin{array}{r}1.5222 \\
(0.8033)\end{array}$ \\
\hline Sport Content & $\begin{array}{l}2.0196 * \\
(0.8966)\end{array}$ & $\begin{array}{r}-16.7301 \\
(2.07 \mathrm{e}+07)\end{array}$ & $\begin{array}{l}2.6764 * * \\
(0.9146)\end{array}$ \\
\hline Economic Content & $\begin{array}{r}0.9236 \\
(0.9241)\end{array}$ & $\begin{array}{r}-16.9134 \\
(5.67 \mathrm{e}+08)\end{array}$ & $\begin{array}{r}1.3790 \\
(0.9398)\end{array}$ \\
\hline National Coverage & $\begin{array}{l}1.2966^{* *} \\
(0.4410)\end{array}$ & $\begin{array}{r}3.0586 \\
(1.8510)\end{array}$ & $\begin{array}{r}0.8792 \\
(0.4822)\end{array}$ \\
\hline Regional Coverage & $\begin{array}{r}0.0180 \\
(0.3166)\end{array}$ & $\begin{array}{l}-1.4272 \\
(1.5227)\end{array}$ & $\begin{array}{l}-0.1583 \\
(0.3396)\end{array}$ \\
\hline Party Affiliation & $\begin{array}{l}1.1166 * * * \\
(0.3509)\end{array}$ & $\begin{array}{l}-0.1621 \\
(0.8632)\end{array}$ & $\begin{array}{l}1.4145 * * \\
(0.4534)\end{array}$ \\
\hline Subsidy & $\begin{array}{l}-0.5809 \\
(0.2688)\end{array}$ & & $\begin{array}{l}-0.8018 \text { ** } \\
(0.2836)\end{array}$ \\
\hline Spanish Language & $\begin{array}{r}1.2274 \\
(1.0509)\end{array}$ & & $\begin{array}{r}14.9297 \\
(1205.078)\end{array}$ \\
\hline Catalan Language & $\begin{array}{r}0.9343 \\
(1.1523)\end{array}$ & & $\begin{array}{r}14.4753 \\
(1205.078)\end{array}$ \\
\hline Basque Language & $\begin{array}{r}1.1564 \\
(1.4614)\end{array}$ & & $\begin{array}{r}14.3916 \\
(1205.078)\end{array}$ \\
\hline Density & $\begin{array}{l}-0.3225 \\
(0.2937)\end{array}$ & $\begin{array}{l}-24.7091 * \\
(11.5132)\end{array}$ & $\begin{array}{l}-0.3170 \\
(0.2926)\end{array}$ \\
\hline Density $2 / 100$ & $\begin{array}{r}0.1059 \\
(0.1178)\end{array}$ & $\begin{array}{l}10.1791 * \\
(4.7948)\end{array}$ & $\begin{array}{r}0.0932 \\
(0.1167)\end{array}$ \\
\hline Market Prospect & $\begin{array}{l}-0.1711 \\
(0.2969)\end{array}$ & $\begin{array}{r}0.3626 \\
(0.5741)\end{array}$ & $\begin{array}{l}-0.1617 * * \\
(0.0476)\end{array}$ \\
\hline Consumption of Newsprint & $\begin{array}{r}0.0620 \\
(0.0446)\end{array}$ & $\begin{array}{r}0.0684 \\
(0.0196)\end{array}$ & $\begin{array}{l}0.0165 * \\
(0.0065)\end{array}$ \\
\hline Gross National Product & $\begin{array}{l}-0.0402 \\
(0.0572)\end{array}$ & $\begin{array}{r}0.0508 \\
(0.0121)\end{array}$ & $\begin{array}{l}-0.0524 \\
(0.0942)\end{array}$ \\
\hline Northern vs. Southern & $\begin{array}{l}0.4227 * \\
(0.2121)\end{array}$ & $\begin{array}{l}-0.1690 \\
(0.5256)\end{array}$ & $\begin{array}{l}0.5175 * \\
(0.2406)\end{array}$ \\
\hline Correction for Self-Selection & $\begin{array}{l}-0.0316 \\
(0.0793)\end{array}$ & $\begin{array}{l}-1.1725 \\
(0.9132)\end{array}$ & $\begin{array}{r}0.0188 \\
(0.0826)\end{array}$ \\
\hline Age $<2$ years & $\begin{array}{l}-2.0146 * * * * \\
(0.4849)\end{array}$ & $\begin{array}{l}-0.3042 * \\
(1.2016)\end{array}$ & $\begin{array}{l}-1.3165 * * \\
(0.4260)\end{array}$ \\
\hline Age $<5$ years & $\begin{array}{l}-0.6664 * * * \\
(0.2005)\end{array}$ & $\begin{array}{l}-0.8732 \\
(0.4534)\end{array}$ & $\begin{array}{l}-0.4456 * \\
(0.1995)\end{array}$ \\
\hline Age $<10$ years & $\begin{array}{l}-0.5201 * * \\
(0.1690)\end{array}$ & $\begin{array}{l}-0.4261 \\
(0.4132)\end{array}$ & $\begin{array}{l}-0.4064 * \\
(0.1793)\end{array}$ \\
\hline Age $<15$ years & $\begin{array}{l}-0.0026 \\
(0.1988)\end{array}$ & $\begin{array}{r}-50.5777 \\
(1237.168)\end{array}$ & $\begin{array}{r}0.2407 \\
(0.2125)\end{array}$ \\
\hline Age $<20$ years & $\begin{array}{r}0.1623 \\
(0.2385)\end{array}$ & 48.4379 & $\begin{array}{r}0.3031 \\
(0.2400)\end{array}$ \\
\hline Age $<25$ years & $\begin{array}{l}-0.9605 \\
(0.5842)\end{array}$ & $\begin{array}{r}-521.165 \\
(1237.168)\end{array}$ & $\begin{array}{l}-0.9473 \\
(0.5774)\end{array}$ \\
\hline Age $<30$ years & $\begin{array}{r}0.6590 \\
(0.5753)\end{array}$ & 523.5399 & $\begin{array}{r}0.4670 \\
(0.6018)\end{array}$ \\
\hline Age $<35$ years & $\begin{array}{l}-0.1831 \\
(0.2599)\end{array}$ & $\begin{array}{l}-0.4925 \\
(0.3652)\end{array}$ & $\begin{array}{l}-0.1849 \\
(0.4251)\end{array}$ \\
\hline
\end{tabular}


Table 3. (Continued)

\begin{tabular}{lccr}
\hline & $\begin{array}{c}\text { Model 1 } \\
\text { Total Period } \\
(1966-1993)\end{array}$ & $\begin{array}{c}\text { Model 2 } \\
\text { Dictatorship } \\
(1966-1977)\end{array}$ & $\begin{array}{c}\text { Model 3 } \\
\text { Democracy } \\
(1978-1993)\end{array}$ \\
\hline Age $<40$ years & 0.1674 & 0.2839 & 0.2229 \\
Age $<45$ years & $(0.2092)$ & $(0.3278)$ & $(0.3362)$ \\
Age $<50$ years & 0.0264 & -324.7144 & 0.0334 \\
Age $>$ 50 years & $(0.1423)$ & & $(0.1572)$ \\
Constant & -0.1942 & $324.3489 * * * *$ & -0.1905 \\
& $(0.1222)$ & $(0.2965)$ & $(0.1305)$ \\
d.f. & 0.0096 & 0.0194 & 0.0125 \\
$\chi^{2}$ & $(0.0087)$ & $(0.0247)$ & $(0.0096)$ \\
Failed newspapers & 25.3518 & $1466.77 * * * *$ & 39.0806 \\
Total newspapers & $(20.4823)$ & $(1.4180)$ & $(1205.296)$ \\
& 32 & 26 & 30 \\
\hline
\end{tabular}

$* * * * p<0.0001 ; * * * p<0.001 ; * * p<0.01 ; * p<0.05$

Standard errors are in parentheses

Over the relatively short period between 1966 and 1993, Spain experienced a rare combination of radical and peaceful changes in its economic, social and political structures. The country witnessed a steady trend towards economic deregulation and market liberalization, moving, after a long tradition of political and economic isolation, from a situation of economic concentration and autarchy towards an active role in the international arena. Spain therefore constitutes a unique social setting to study how organizations deal with their everchanging environments - especially firms with significantly ambiguous goals, like newspapers, which intermingle the features of both production and institutionalized organizations (Meyer and Rowan 1977; Carroll 1995). Newspapers fit into Hannan and Freeman's (1984) category of highly political firms that deliver information-loaded products and therefore face strong institutional pressures for independently certified performance. Hence they give us ways to examine the implications of such certification for organizational failure.

Our findings rely on the quality of the databases used in this investigation. First, the databases are comprehensive and supply time-varying covariates, allowing us to explore a possible causal relationship between certification and organizational failure. Second, they capture the link between newspaper organizations and the population of advertising companies and the society at large: the OJD audits provided constituents with accurate circulation figures (Aguado Guadalupe 1996) on which to base decisions about where to advertise, thereby supplying firms with an exceptionally large proportion of their total income. Because the data themselves were equally reliable during the Dictatorship and the Democracy, we can conclude that it was the value placed on independent certification of performance that varied across political regimes.

This paper supports the prediction that the selective effects of independently certified performance are contingent upon political regimes and are therefore higher in periods of democracy than in those of dictatorship. During our 
Dictatorship period (1966-1977), firms had to cope with the overriding presence of the state, which had the power to recall newspapers, temporarily suspend the publication of dailies that published news that was incompatible with governmental dictates and even impose by decree the cessation of newspaper operations (e.g. the Madrid, in 1971). In contrast, dailies complying with the media policy of the dictatorship avoided sanctions, obtained advertising from publicsector organizations and enjoyed state protection in the form of refusal to license competitors in their geographical area (Terrón Montero 1981). Thus, the state intervened between market forces and firm survival.

Conversely, during the period of Democracy (1978-1993), the demand for independently certified performance pervaded the organizational terrain and exerted its selective effects on firms. Advertising companies, of course, represent a substantial segment of the newspaper business process (Sohn et al. 1986), which consists of the sale of newspaper issues to readers - one-third of newspaper total revenues - and the subsequent 'sale' of the reader to advertisers - two-thirds of total revenues. Obviously, newspaper organizations are highly dependent upon the resources supplied by advertisers (Pfeffer and Salancik 1978).

The liberalization of the Spanish economy that accompanied the transition from dictatorship to democracy accentuated the importance of the advertising industry and its need to use reliable data on newspaper circulations (Aguado Guadalupe 1996). According to reports on the market for publicity by Nielsen Repress, the number of advertisements published in Spanish newspapers increased from 38,630 in 1976 to 100,478 in 1992, which in turn increased the number of equivalent full pages containing advertisements from 33,240 in 1976 to 78,230 in 1992 . These increases resulted in a significant growth in the volume of total investments made by advertising agencies in newspaper publicity according to Nielsen Repress, from US\$200 million in 1975 to US\$1.575 billion in 1993. Together, these market data depict the advertising sector in Spain as an expanding industry.

The results of the present study support the prediction that institutional processes are not monolithic and do not always elicit conformity and compliance from organizations (Oliver 1991; Scott and Meyer 1994). Pressures for compliance with institutional norms are contingent upon political contexts and, as in this case under the dictatorship of General Franco, organizations are prone to dismiss institutional demands 'when the potential for external enforcement of institutional rules is perceived to be low' (Oliver 1991: 156).

One control variable, party affiliation, showed a positive coefficient and strong significance during the Democracy. This finding indicates the absence of significant differences between the failure rates of newspapers affiliated and non-affiliated to the single party during the Dictatorship. In contrast, the chances of failure of Falangist newspapers were significant during the Democracy, especially for those that did not request OJD audits. In general, this finding suggests that values pervading newspaper organizations in democracies, such as reliability and trust, may have replaced those of ideological conformity that characterized the dictatorship of General Franco and applied to newspapers both affiliated and non-affiliated with the single party. 
The limitations of this study should encourage further work in this area. First, Spanish society underwent a turbulent period of change, which forged strong institutional and market pressures for organizational accountability, especially during the Democratic period. Ultimately, these intense pressures could be attributed to a social reaction against the authoritarian environment that characterized the Dictatorship. Only further research into the relationship between independently certified performance and organizational failure conducted in more stable settings will shed light on the generalizability of the consequences associated with certification. Second, the newspaper industry is significantly exposed to pressures for independently certified performance. We therefore suggest that future work on populations that do not fit into Hannan and Freeman's categories of organizations experiencing such strong pressures will reveal the generalizability of our findings. Third, because we used a nationwide unit of analysis, we could not distinguish between pressures for independently certified performance from sources that seem to predominate at the local level (e.g. market forces: cf. Dacin 1997) and those operating at the global level (e.g. institutional prescriptions). Finer-grained data may reveal the extent to which such pressures stem from local and global sources. Fourth, we relied on coverage variables (national, regional and local) as proxies of size. The development of less coarse-grained indicators of size for the entire population provides considerable potential for future work. Finally, our results suggest the existence of a causal link between independently certified performance and probability of failure, all else being equal. Because of our lack of circulation data on nonOJD-affiliated newspapers, we could not identify the extent to which the process of independent certification could capture the effects of variables such as size and performance on organizational failure.

This paper has focused on the failure implications of independently certified performance under varying political circumstances. Our central proposition has been tested in the unique social laboratory provided by Spanish society during the period 1966-1993, which witnessed the replacement of a military dictatorship by a capitalist democracy. This setting allowed us to discern the consequences of the value attributed to the process of certifying performance (specifically, failure) under these political regimes. The findings of this study highlight that the effects of institutions on organizations are not monolithic but are contingent upon changes experienced by the socio-economic and political contexts of firms. Finally, we suggest that examination of the specifics of the varying relationship between institutions and organizations deserves further research on the part of students of organizations. Such studies, we argue, may focus on countries and regions whose political environments have experienced dramatic patterns of change over a relatively short period of time (e.g. Eastern Europe, Latin America and South Africa). 2004-08176-C02-01/02, 01-0657 and SEC03-3797. We are particularly grateful to Senior Editor Roger Dunbar for his constructive comments and guidance during the review process. We would also like to thank Mahmoud Ezzamel, Antonio García-Ferrer, Michael Hitt, Henry Tosi and the three anonymous reviewers of Organization Studies for their many helpful suggestions on earlier versions of this paper. 
References
Aguado Guadalupe, Guadalupe

1996 OJD y el control de la difusión de la prensa en España. Madrid: Ariel Comunicación.

Álvarez, Jesús T.

1989 Historia de los medios de comunicación social en España: Periodismo, imagen y publicidad (1900-1990). Barcelona: Ariel Comunicación.

Baum, Joel A. C., and Helaine J. Korn

1996 'Competitive dynamics of interfirm rivalry'. Academy of Management Journal 39: 255-291.

Baum, Joel A. C., and Stephen J. Mezias

1992 'Localized competition and organizational failure in the Manhattan hotel industry, 1898-1990'. Administrative Science Quarterly 37: 580-604.

Biglaiser, Gary

1993 'Middlemen as experts'. RAND Journal of Economics 24: 212-223.

Bobbio, Norberto

1989 Democracy and dictatorship: The nature and limits of state power. Cambridge: Polity.

Bordería Ortiz, Enrique

2000 La prensa durante el Franquismo: Represión, censura y negocio. Valencia: Fundación Universitaria CEU.

Carroll, Glenn R.

1985 'Concentration and specialization: Dynamics of niche width in populations of organizations'. American Journal of Sociology 90: 1262-1283.

Carroll, Glenn R.

1995 'Newspaper publishers' in Organizations in industry. Glenn R. Carroll and Michael T. Hannan (eds), 183-194. New York: Oxford University Press.

Carroll, Glenn R., and Jacques Delacroix

1982 'Organizational mortality in the newspaper industries of Argentina and Ireland: An ecological approach'. Administrative Science Quarterly 27: 169-198.

Carroll, Glenn R., and Michael T. Hannan

1989 'Density dependence in the evolution of newspaper organizations'. American Sociological Review 54: 524-541.
Carroll, Glenn R., and Michael T. Hannan

2000 The demography of corporations and industries. Princeton, NJ: Princeton University Press.

Cox, David R., and David Oakes

1984 Analysis of survival data. London: Chapman and Hall.

Dacin, M. Tina

1997 'Isomorphism in context: The power and prescription of institutional norms'. Academy of Management Journal 40: 46-81.

Dacin, M. Tina, Jerry Goodstein, and W.

Richard Scott

2002 'Institutional theory and institutional change: Introduction to the special research forum'. Academy of Management Journal 43: 45-57.

DiMaggio, Paul J., and Walter W. Powell

1983 'The iron cage revisited: Institutional isomorphism and collective rationality in organizational fields'. American Sociological Review 48: 147-160.

Dobrev, Stanislav D.

2001 'Revisiting organizational legitimation: Cognitive diffusion and sociological factors in the evolution of Bulgarian newspaper enterprises, 1846-1992'. Organization Studies 22: 419-444.

Dobrev, Stanislav D., and Glenn R. Carroll

2003 'Size (and competition) among organizations: Modeling scale-based selection among automobile producers in four major countries, 1885-1981'. Strategic Management Journal 24: 541-558.

Fernández Areal, Manuel

1971 La ley de prensa, a debate. Barcelona: Plaza \& Janés.

Friedrich, Carl J.

1950 Constitutional government and democracy: Theory and practice in Europe and America. Boston, MA: Ginn.

Greene, William H.

1993 Econometric analysis, 2nd edn. New York: Macmillan.

Hannan, Michael T., and John Freeman

1984 'Structural inertia and organizational change'. American Sociological Review 49: 149-164.

Hannan, Michael T., and John Freeman

1989 Organizational ecology. Cambridge, MA: Harvard University Press. 
Hannan, Michael T., Glenn R. Carroll, Stanislav D. Dobrev, and Joon Han 1998 'Organizational mortality in European and American automobile industries. Part I: Revisiting the effects of age and size'. European Sociological Review 14/3: 279-302.

Heckman, James J.

1979 'Sample selection bias as a specification'. Econometrica 47: 153-161.

Imhoff Jr, Eugene A.

2003 'Accounting quality, auditing, and corporate governance'. Accounting Horizons Supplement Issue 17: 117-128.

Ingram, Paul, and Tal Simons

2000 'State formation, ideological competition, and the ecology of Israeli workers' cooperatives, 1920-1992'. Administrative Science Quarterly 45: 25-53.

Kim, Bongjin, and John E. Prescott

2005 'Deregulation forms, variations in the speed of government adaptation, and firm performance'. Academy of Management Review 30: 414-425.

La Caixa

2005 Informe annual 2005. Barcelona: La Caixa.

Lawless, Jerald F.

1982 Statistical models and methods for lifetime data. New York: Wiley.

Lizzeri, Alessandro

1999 'Information revelation and certification intermediaries'. RAND Journal of Economics 30: 214-231.

Maddala, G. S.

1983 Limited-dependent and qualitative variables in econometrics. Cambridge: Cambridge University Press.

Mahmood, Ishtiaq P., and Carlos Rufin

2005 'Government's dilemma: The role of government in imitation and innovation'. Academy of Management Review 30: 338-360.

Meyer, John W., and Brian Rowan

1977 'Institutionalized organizations: Formal structure as myth and ceremony'. American Journal of Sociology 83: 340-363.

Meyer, John W., and W. Richard Scott

1983 'Centralization and the legitimacy problems of local government' in Organizational Environments: Ritual and Rationality. John W. Meyer and W. Richard Scott (eds), 199-215. Beverly Hills, CA: Sage.

Meyer, John W., John Boli, and George M. Thomas

1987 'Ontology and rationalization in Western cultural account' in Institutional structure: Constituting state, society, and the individual.

George M. Thomas, John W. Meyer, Francisco O. Ramirez and John Boli (eds), 12-37. Newbury Park, CA: Sage.

Mezias, Stephen J., and Mario Scarselletta

1994 'Resolving financial reporting problems: An institutional analysis of the process'. Administrative Science Quarterly 39: 654-678.

Miner, Anne S., Terry L. Amburgey, and Timothy M. Stearns

1990 'Interorganizational linkages and population dynamics: Buffering and transformational shields'.

Administrative Science Quarterly 35: 689-713.

Oliver, Christine

1991 'Strategic responses to institutional processes'. Academy of Management Review 16: 145-179.

Pfeffer, Jeffrey, and Gerald R. Salancik

1978 The external control of organizations: A resource dependence perspective. New York: Harper and Row.

Pye, Lucian W. editor

1963 Communications and political development. Princeton, NJ: Princeton University Press.

Rao, Hayagreeva

1998 'Caveat emptor: The construction of nonprofit consumer watchdog organizations'. American Journal of Sociology 103: 912-961.

Ring, Peter Smith, Gregory A. Bigley,

Thomas D'Aunno, and Tarun Khanna

2005 'Introduction to special topic forum. Perspectives on how governments matter'. Academy of Management Review 30: 308-320.

Salancik, Gerald R., and James R. Meindl

1984 'Corporate attributions as strategic illusions of management control'. Administrative Science Quarterly 29: 238-254.

Scott, W. Richard

1995 Institutions and organizations. Thousand Oaks, CA: Sage. 
Scott, W. Richard

2001 Institutions and organizations, 2nd edn. Thousand Oaks, CA: Sage.

Scott, W. Richard, and John W. Meyer

1994 Institutional environments and organizations. Thousand Oaks, CA: Sage.

Sevillano Calero, Francisco

1998 Propaganda y medios de comunicación en el Franquismo. Alicante: Publicaciones de la Universidad de Alicante.

Shaver, J. Myles

1998 'Accounting for endogeneity when assessing strategy performance. Does entry mode choice affect FDI survival?' Management Science 44: 571-585.

Skocpol, Theda

1985 'Bringing the state back in: States of analysis in current research' in Bringing the state back in. P. Evans, D. Rueschemeyer and T. Skocpol (eds), 3-37. Cambridge: Cambridge University Press.
Sohn, Ardyth, Christine Ogan, and John Polich

1986 Newspaper leadership. Englewood Cliffs, NJ: Prentice Hall.

Stepan, Alfred

1978 The state and society. Princeton, NJ: Princeton University Press.

Suchman, Mark

1995 'Managing legitimacy: Strategic and institutional approaches'. Academy of Management Review 20: 571-610.

Terrón Montero, José

1981 La prensa española durante el régimen de Franco: Un intento de análisis político. Madrid: CIS.

Valls, Juan F.

1986 La jungla comunicativa. Barcelona: Ariel Comunicación.

Watts, Ross L., and Jerold Zimmerman

1983 'Agency problems, auditing and the theory of the firm'. Journal of Law and Economics 26: 613-633.

\section{Manuel Núñez-Nickel}

Isabel Gutiérrez

Salvador Carmona
Manuel Núñez-Nickel is an associate professor of accounting and finance at Carlos III University, from which he received his $\mathrm{PhD}$. He has published in Academy of Management Journal and Journal of Management Studies. His main area of interest is the interrelationship between audit practice and its wider contexts.

Address: Department of Business Administration, Carlos III University, Calle Madrid, 126, 28903 Getafe, Spain.

Email:mnunez@emp.uc3m.es

Isabel Gutiérrez is a professor of management at Carlos III University. She received her $\mathrm{PhD}$ from the University of Seville. Her articles have been published in Academy of Management Journal and Academy of Management Review, and she is co-editor of Management Research. Her main area of interest is macro-organizational theory and industrial dynamics.

Address: Department of Business Administration, Carlos III University, Calle Madrid, 126; 28903 Getafe, Spain.

Email: isagut@eco.uc3m.es

Salvador Carmona is a professor of accounting and management control at Instituto de Empresa Business School. His articles have been published in Accounting, Organizations and Society and Journal of Accounting and Public Policy. He is the new editor of European Accounting Review. His main area of interest is the organizational and social aspects of accounting systems.

Address: Instituto de Empresa Business School, Calle María de Molina, 12-5, Madrid, Spain. Email: salvador.carmona@ie.edu 